\title{
Distribution and habitat preference of Bombus (Kallobombus) soroeensis (Fabricius, 1777) on the territory of Arkhangelsk Region
}

\author{
GS Potapov ${ }^{1}$, YuS Kolosova ${ }^{1}$ \\ 1 Federal Center for Integrated Arctic Research, Russian Academy of Sciences (Arkhangelsk, Russian Federation) \\ Corresponding author: Grigory Potapov (grigorij-potapov@yandex.ru)
}

Academic editor: Yuliya V. Bespalaya • Received 9 May 2018 • Accepted 20 June 2018 • Published 9 July 2018

Citation: Potapov GS, Kolosova YuS (2018) Distribution and habitat preference of Bombus (Kallobombus) soroeensis (Fabricius, 1777) on the territory of Arkhangelsk Region. Arctic Environmental Research 18(2): 66-70. https://doi.org/10.3897/issn2541-8416.2018.18.2.66

\begin{abstract}
In this paper, we summarise material pertaining to the distribution and habitat preference of Bombus (Kallobombus) soroeensis (Fabricius, 1777) on the territory of Arkhangelsk Region. B. soroeensis is widely represented on the territory as nominative subspecies $B$. soroeensis ssp. soroeensis, which is common mainly in Fennoscandia, the British Isles and Eastern Europe. The northern border of the species range in the Arkhangelsk Region is the lower reaches of the Mezen River, located in the transition zone between the northern taiga and the forest-tundra. This locality is probably one of the most northern records of this species in the northern part of the Russian Plain. In Eastern Fennoscandia, B. soroeensis is distributed far to the north, i.e., in the northern parts of Finland and Norway. In relation to the habitat preference, B. soroeensis in the study region belongs to the category of meadow species. This species is typical of different types of meadows and ruderal habitats. B. soroeensis is not typical with regards to the native taiga habitats, in most cases. This is similar to the situation on the territory of Finland, where this species is associated with open meadow habitats. Individuals of $B$. soroeensis have been recorded on a wide range of entomophilous plants, and the main examples are Rhinanthus minor, Epilobium angustifolium, Cirsium arvense, Scorzoneroides autumnalis, Lotus corniculatus.
\end{abstract}

\section{Keywords}

Bombus soroeensis, European North, species range, habitat preference

Bombus (Kallobombus) soroeensis (Fabricius, 1777) is widely distributed in Europe where this species is quite well studied (Rasmont et al. 2015). However, mate- rial from the European North of Russia is not so abundant. There are a number of documented examples from Karelia (especially concerning the southern part

Copyright Potapov GS \& Kolosova YuS. This is an open access article distributed under the terms of the Creative Commons Attribution License (CC-BY 4.0), which permits unrestricted use, distribution, and reproduction in any medium, provided the original author and source are credited. 
of this region), Komi Republic (Pekkarinen et al. 1981, Söderman and Leinonen 2003, Rasmont and Iserbyt 2018). The collecting localities from the Arkhangelsk Region are summarised in the checklist of Potapov and Kolosova (2016) for bumblebees of this region.

The study of distribution and habitat preference of $B$. soroeensis is important in connection with the forecasts of changes in the species range under global warming (Rasmont et al. 2015). According to the available models, a significant reduction in suitable area in Europe for this species is expected by 2050 (Rasmont et al. 2015).

In this paper, we analyse the distribution of $B$. soroeensis on the territory of Arkhangelsk Region and its habitat preference.

\section{Materials and methods}

Bumblebees were collected in different localities of the Arkhangelsk Region during the period 19942017 (Table 1). It was studied the various types of communities. The collecting localities are shown on the map of this region (Fig. 1). Bumblebees were caught with an entomological net. A total of 528 individuals of $B$. soroeensis were studied.

The specimens of bumblebees are deposited in the Russian Museum of the Biodiversity Hotspots (RMBH), Federal Center for Integrated Arctic Research (FCIARctic), Russian Academy of Sciences (RAS), Arkhangelsk, Russia.
The nomenclature follows Williams (2018). Bumblebees were identified according to Løken (1973), Panfilov (1978), Intoppa et al. (2009), Rasmont and Terzo (2010). The plant species are given according to The Plant List (2013). In order to study the types of communities, we used the materials of Shmidt (2005) and Parinova et al. (2014).

The map of the Arkhangelsk Region was produced by using ArcGIS 10.0 software.

\section{Results}

In the list of the studied material we give locality, data, number of specimens, habitat where bumblebees were caught, and the name of the collector. This list of materials, except for some localities, is documented in the work of Potapov and Kolosova (2016). In the present paper, we include material from a number of additional localities.

Material examined: Mezen, 12.VII.2015, 18-19.VII.2015, 4ళ్ , wet meadow in floodplain, meadow-like habitat, coniferous forest, Potapov and Pinaevskaya leg.; Golubino, 25-27.VIII.2000, 25-31.VIII.2004, 3ర్థ, 29 , wet meadow in floodplain, Bolotov and Kolosova leg.; Arkhangelsk, 2.VII.-31.VIII.2010, 41ర్థ, 28ð, ruderal community, wet meadow in floodplain, roadside, agroecosystem, meadow-like habitat, Potapov and Podbolotskaya leg.; Kholmogory, 16-21.VIII.2010, 32ఫ, $45 \hat{\jmath}$, roadside, ruderal community, agroecosys-

Table 1. The collecting localities of B. soroeensis in the Arkhangelsk Region

\begin{tabular}{c|l|c|c}
\hline \multicolumn{1}{c|}{ Localities } & Latitude (N) & Longitude (E) \\
\hline 1 & Mezen & $65^{\circ} 49^{\prime}$ & $44^{\circ} 13^{\prime}$ \\
\hline 2 & Golubino & $64^{\circ} 33^{\prime}$ & $43^{\circ} 15^{\prime}$ \\
\hline 3 & Arkhangelsk and delta of the North Dvina River & $64^{\circ} 32^{\prime}$ & $40^{\circ} 26^{\prime}$ \\
\hline 4 & Kholmogory & $64^{\circ} 14^{\prime}$ & $41^{\circ} 37^{\prime}$ \\
\hline 5 & Solza River & $64^{\circ} 29^{\prime}$ & $39^{\circ} 32^{\prime}$ \\
\hline 6 & Onega & $63^{\circ} 54^{\prime}$ & $38^{\circ} 07^{\prime}$ \\
\hline 7 & Bolshoy Bor & $63^{\circ} 36^{\prime}$ & $39^{\circ} 06^{\prime}$ \\
\hline 8 & Mirniy & $62^{\circ} 46^{\prime}$ & $40^{\circ} 18^{\prime}$ \\
\hline 9 & Kenozero Lake & $62^{\circ} 04^{\prime}$ & $38^{\circ} 11^{\prime}$ \\
\hline 10 & Shenkursk & $62^{\circ} 06^{\prime}$ & \\
\hline 11 & Verkhnyaya Toyma & $62^{\circ} 13^{\prime}$ & \\
\hline 12 & Abakumovo & $61^{\circ} 35^{\prime}$ & $45^{\circ} 53^{\prime}$ \\
\hline 13 & Svyatoe Lake & $60^{\circ} 51^{\prime}$ & $32^{\prime} 04^{\prime}$ \\
\hline 14 & Ilyinsko-Podomskoe & $61^{\circ} 07^{\prime}$ & $39^{\circ} 31^{\prime}$ \\
\hline
\end{tabular}




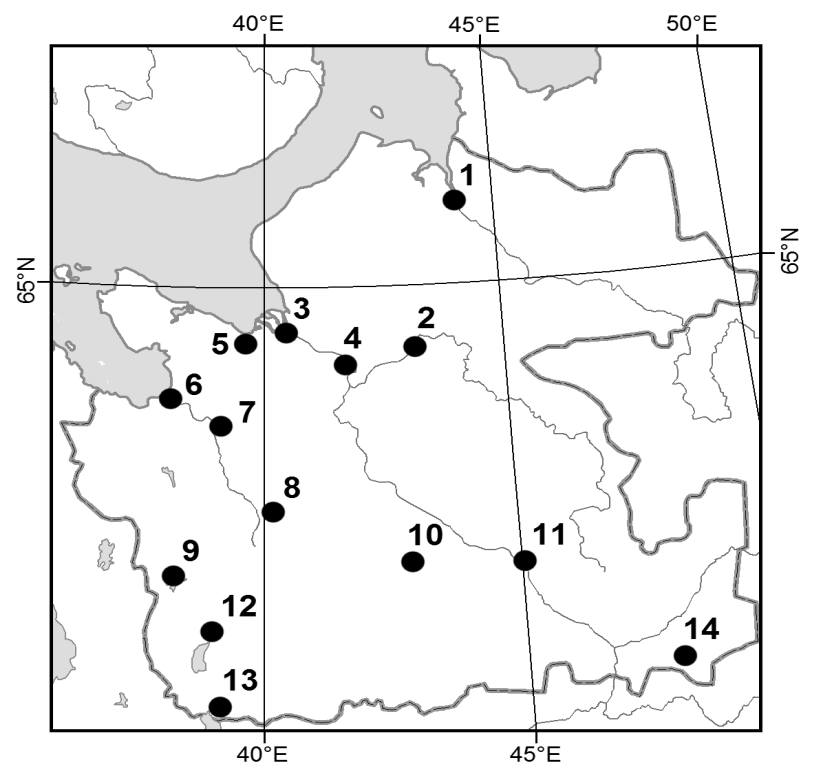

Fig. 1. Map of the Arkhangelsk Region. Numbers for the collecting localities are given in Table 1

tem, meadow-like habitat, wet meadow in floodplain, Potapov and Podbolotskaya leg.; Solza River, 3.IX.2005, 2§, wet meadow in floodplain, Kolosova and Bespalaya leg.; Onega, 6.VIII.2017, 1ఫ, ruderal community, Potapov leg.; Bolshoy Bor, 14-

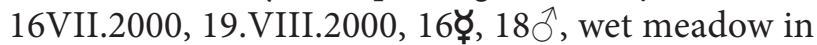
floodplain, ruderal community, Bolotov leg.; Mir-

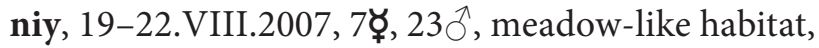
roadside near forest, Kolosova leg.; Kenozero Lake, 10-11.VIII.2004, 12-17.VIII.2008, 37ర్ఘ, 20, dry meadow, roadside, meadow-like habitat, Kolosova and Podbolotskaya leg.; Shenkursk, 19-29.VII.2001, 2.VIII.2001，21.VI.2014，30.VII.-6.VIII.2015，85ర్ఘ, $60{ }^{\lambda}$, dry meadow, ruderal community, meadow-like habitat, roadside, Potapov, Pinaevskaya and Iglovsky leg.; Verkhnyaya Toyma, 24.VII.-12.VIII.2000,

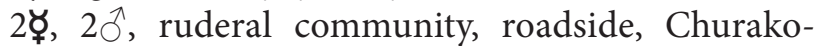

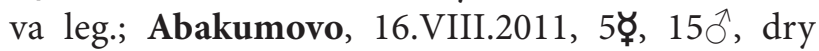
meadow, Potapov and Podbolotskaya leg.; Svyatoe Lake, 26-30.VIII.2003, 15-16.VIII.2007, 12ఫ్, 53 §ૈ, dry meadow, meadow-like habitat, roadside, Kolosova and Podbolotskaya leg.; Ilyinsko-Podomskoe, 25.VII.-29.VIII.1994, 2-31.VIII.1996, 2ఫ్, 4§ิ, wet
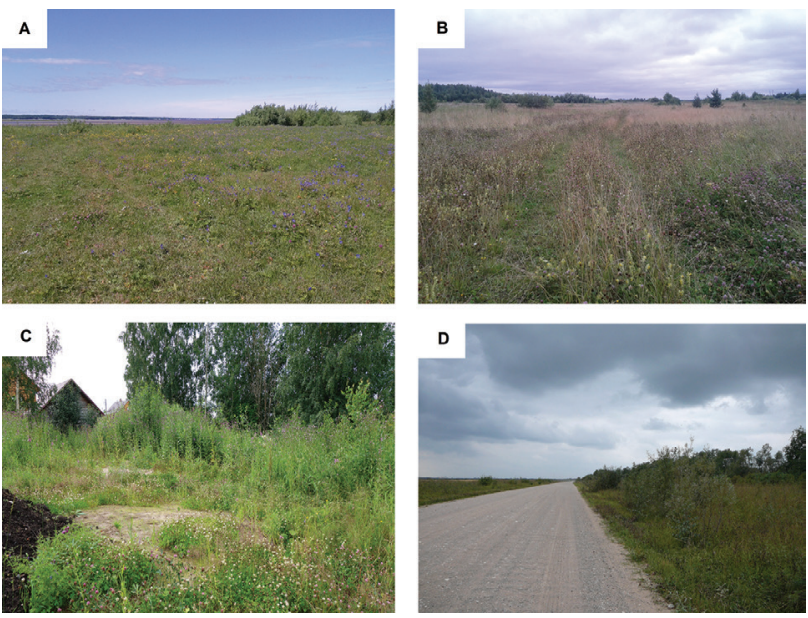

Fig. 2. Typical foraging habitats of B. soroeensis in the Arkhangelsk Region: (A) Wet meadow in floodplain, Mezen; (B) Dry meadow, Shenkursk; (C) Ruderal community, Onega; (D) Roadside, Kholmogory. Photos: GS Potapov.

meadow in floodplain, dry meadow, ruderal community, roadside near forest, Filippov leg.

The typical foraging habitats of $B$. soroeensis in the Arkhangelsk Region are shown in Fig. 2:

1) Wet meadows are spread along almost all largeand medium-sized rivers in the Arkhangelsk Region. Their area is particularly expansive on the banks of the Northern Dvina, Mezen, and Pinega (Shmidt 2005).

2) Dry meadows are widespread primarily in the southern part of the Arkhangelsk Region (Shmidt 2005). They are usually secondary meadows that have emerged from the destruction of forests in the region (Parinova et al. 2014).

3) Ruderal communities are different types of secondary meadow and meadow-like habitats. They are formed as a result of human activities.

4) Roadsides are not distinguished as a separate type of community. However, they are the locations of concentration of numerous bumblebees, hence we categorise them in a separate group. 


\section{Discussion}

The studied species in the Arkhangelsk Region is represented as the nominative subspecies $B$. soroeensis ssp. soroeensis, which is common in Fennoscandia, the British Isles, Eastern Europe and a number of other regions of the European continent (Reinig 1939, Løken 1973, Dylewska 1996).

In general, $B$. soroeensis is widely represented in the Arkhangelsk Region (Fig. 1). The northern border of the species range in this region is located at latitude $65^{\circ} \mathrm{N}$. This is the lower reaches of the Mezen River. On the territory of the Komi Republic the northern border is also located at around $65^{\circ} \mathrm{N}$ (Filippov 2007, Rasmont and Iserbyt 2018). These are probably the most northern localities of the record of B. soroeensis in the northern part of the Russian Plain.

The studied area of the lower reaches of the Mezen River is located in the transition zone between the northern taiga and the forest-tundra (Fedorov 1976). Here, there are wet meadows in the floodplain and different types of ruderal habitats. The presence of B. soroeensis in northern localities that are similar to Mezen is explained by the fact that the studied area is located in the river basin. It is known that river valleys play a considerable role in the expansion of a number of bumblebee species, which are not typical of zonal taiga or tundra landscapes. This pattern was previously shown for the European North of Russia (Kolosova and Potapov 2011).

In Eastern Fennoscandia, the forest boundary has been shifted northwards due to frequent invasions of humid Atlantic air masses and the influence of the ice-free Barents Sea (Isachenko 1995). For this reason, B. soroeensis is found far to the north, i.e., in the northern parts of Finland and Norway (Løken 1973, Pekkarinen et al. 1981, Söderman and Leinonen 2003, Rasmont and Iserbyt 2018).

Typical foraging habitats of $B$. soroeensis on the territory of the Arkhangelsk Region are various types of meadow and ruderal communities (Fig. 2). Only in the lower reaches of the Mezen River was this species foraging on the heather community (Calluna vulgaris (L.) Hull) in the pine forest. However, for the native taiga habitats, $B$. soroeensis are not typical in most cases.

In the region under study, $B$. soroeensis visited a wide range of entomophilous plants, the main plants of which are Rhinanthus minor L., Epilobium angustifolium L., Cirsium arvense (L.) Scop., Scorzoneroides autumnalis (L.) Moench, Lotus corniculatus L.

On the territory of Finland, as well as in the Arkhangelsk Region, B. soroeensis is associated with open meadow habitats (Söderman and Leinonen 2003). However, in a number of other regions of Europe the habitat preference of $B$. soroeensis is different. For example, in the British Isles this species is associated not only with meadow habitats, but also with heathlands and woodlands (Falk and Lewington 2017). In Eastern Europe, B. soroeensis prefers forest edges in addition to open meadow habitats (Panfilov 1957, Dylewska 1996). In southern Europe, B. soroeensis occurs mainly in mountain forest habitats (Hagen 1986, Iserbyt 2009, Manino et al 2010, Rasmont et al. 2015). On the European continent as a whole, there has been a change in the habitat preference of this species from mountain ecosystems in southern Europe to open plains in the northern part of the European continent (Rasmont et al. 2015). Here is an example of the rule of zonal change of habitats within the species range, in that the species inhabits forest communities in the south of its range and it associates to open habitats in the north (Bey-Bienko 1966).

\section{Conclusion}

The territory of the Arkhangelsk Region can be considered as one of the northern borders of $B$. soroeensis in the north-east of the European continent. In relation to habitat preference, $B$. soroeensis is typical of open meadow habitats, similarly for Eastern Fennoscandia.

We expect a stable existence of this species in the Arkhangelsk Region. Further monitoring is needed in connection with the expected changes in the species range in the next few decades (Rasmont et al. 2015). 


\section{Acknowledgements}

The study was supported by the federal programme of the FCIARctic (no. 0409-2015-0141). The authors are grateful to PhD MV Podbolotskaya (1956-2014) for assistance in collecting material. Also, assistance in the collection of material was provided by EA Pinaevskaya.
We thank Dr. Sc. IN Bolotov, Dr. Sc. BYu Filippov, $\mathrm{PhD}$ YuV Bespalaya, PhD SA Iglovsky and PhD EYu Churakova for providing material from a number of localities in the Arkhangelsk Region. Also, we are grateful to $\mathrm{PhD} \mathrm{MYu}$ Gofarov for providing the map of the Arkhangelsk Region. Special thanks are due to Dr. M. Copley for improving the language of the paper.

\section{References}

- Bey-Bienko GY (1966) General entomology. Vysshaya shkola, Moscow, $496 \mathrm{pp}$.

- Dylewska M (1996) Nasze trzmiele. Ośrodek Doradztwa Rolniczego, Karniowice, 256 pp.

- Falk S, Lewington R (2017) Field guide of the bees of Great Britain and Ireland. Bloomsbury, London, $432 \mathrm{pp}$.

- Fedorov VD (1976) Atlas of Arkhangelsk Region. General department of geodesy and cartography, Moscow, $72 \mathrm{pp}$.

- Filippov NI (2007) Bumblebees (Apidae, Bombus) of complex reserve Pizhemskiy. Proceedings of I (XIV) Russian conference for young scientists "Actual problems of biology and ecology". Institute of biology of Komi Scientific Centre, Syktyvkar, 269-271.

- Hagen von E (1986) Hummeln - bestimmen, ansiedeln, vermehren, schützen. Neumann-Neudamm, Melsungen, 221 pp.

- Intoppa F, Piazza MG, Bolchi Serini G, Cornalba M (2009) I Bombi. Guida al riconoscimento delle specie Italiane. Unità di Ricerca di Apicoltura e Bachicoltura, Bologna, 177 pp.

- Isachenko AG (1995) Physical and geographical characteristics of the region. State of the environment in the North-Western and Northern regions of Russia. Nauka, Saint-Petersburg, 7-30.

- Iserbyt S (2009) La faune des bourdons (Hymenoptera: Apidae) du Parc National des Pyrénées occidentales et des zones adjacentes. Annales de la Société entomologique de France (NS) 45(2): 217-244. https://doi.org/10.1080/00379271.2009.10697603

- Kolosova YuS, Potapov GS (2011) Bumblebees (Hymenoptera, Apidae) in the forest-tundra and tundra of Northeast Europe. Entomological Review 91(7): 830-836. https://doi. org/10.1134/S0013873811070049

- Løken A (1973) Studies of Scandinavian bumblebees (Hymenoptera, Apidae). Norsk Entomologisk Tidsskrift 20(1): $1-218$.

- Manino A, Patetta A, Boglietti G, Porporato M (2010) Bumblebees of the Susa Valley (Hymenoptera: Apidae). Bulletin of Insectology 63(1): 137-152.

- Panfilov DV (1957) Bumblebees (Bombidae) of the Moscow Region. Uchenye zapiski Moskovskogo gorodskogo pedagogicheskogo instituta imeni V.P. Potemkina 65: 191-219.
- Panfilov DV (1978) Key to species of the Family Apidae Bees. Key to insects of the European Part of the USSR. Nauka, Leningrad 3(1): 508-519.

- Parinova TA, Nakvasina EN, Sidorova OV (2014) Meadows of the island floodplain in the delta of the North Dvina River. Northern (Arctic) Federal University, Arkhangelsk, 146 pp.

- Pekkarinen A, Teräs I, Viramo J, Paatela J (1981) Distribution of bumblebees (Hymenoptera, Apidae: Bombus and Psithyrus) in eastern Fennoscandia. Notulae Entomologicae 61: 71-89.

- Potapov GS, Kolosova YS (2016) Fauna of bumblebees (Hymenoptera: Apidae: Bombus Latr.) in the mainland part of Arkhangelsk Region, NW Russia. Annales de la Société entomologique de France (NS) 52(3): 150-160. https://doi.org/10. 1080/00379271.2016.1217167

- Rasmont P, Terzo M (2010) Catalogue et clé des sous-genres et espèces du genre Bombus de Belgique et du nord de la France (Hymenoptera, Apoidea). Mons University, Mons, 28 pp.

- Rasmont P, Franzén M, Lecocq T, Harpke A, Roberts S, Biesmeijer J, Castro L, Cederberg B, Dvorak L, Fitzpatrick Ú, Gonseth Y, Haubruge E, Mahé G, Manino A, Michez D, Neumayer J, Ødegaard F, Paukkunen J, Pawlikowski T, Potts S, Reemer M, Settele J, Straka J, Schweiger O (2015) Climatic Risk and Distribution Atlas of European Bumblebees. BioRisk 10: 1-236. https://doi.org/10.3897/biorisk.10.4749

- Rasmont P, Iserbyt S (2018) Atlas of the European Bees: genus Bombus. Mons University, Mons. http://www.zoologie.umh. ac.be//hymenoptera/page.asp?ID=169

- Reinig WF (1939) Die Evolutionsmechanismen, erläutert an den Hummeln. Verhandlungen der Deutschen Zoologischen Gesellschaft Supplement 12: 170-206.

- Shmidt VM (2005) Flora of the Arkhangelsk Region. Saint-Petersburg University, Saint-Petersburg, 346 pp.

- Söderman G, Leinonen R (2003) Suomen mesipistiäiset ja niiden uhanalaisuus. Tremex Press, Helsinki, 420 pp.

- The Plant List (2013) Version 1.1. http://www.theplantlist.org/

- Williams PH (2018) Bumblebees of the World. The Natural History Museum, London. http://www.nhm.ac.uk/research-curation/projects/bombus/index.html 